\title{
Little Blue Cattle Louse Solenopotes capillatus (Enderlein) (Insecta: Phthiraptera: Anoplura: Linognathidae) ${ }^{1}$
}

Kevyn J. Juneau and Phillip E. Kaufman²

\section{Introduction}

Of the five sucking lice that feed on cattle in Florida (Kaufman et al. 2007), Solenopotes capillatus (Enderlein) is the smallest in size (Grubbs et al. 2007). The little blue cattle louse, as it is commonly called, is in the family Linognathidae (the pale lice) and is one of the nine currently recognized species in the genus Solenopotes (Durden and Musser 1994).

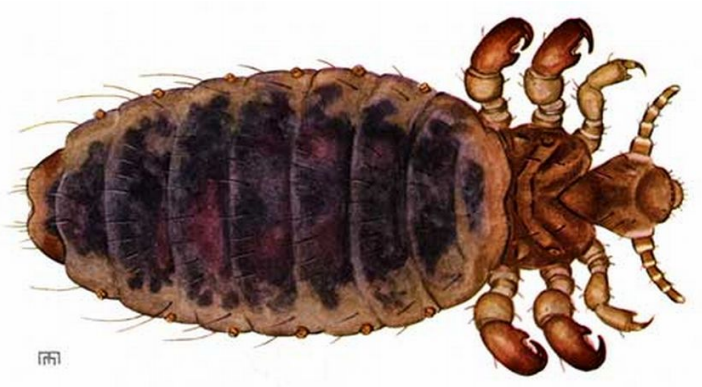

Figure 1. Adult little blue cattle louse, Solenopotes capillatus (Enderlein). Credits: Ellen Edmonson, Cornell University Agricultural Experiment Station, Bulletin No. 832. Used with permission

\section{Distribution}

Solenopotes capillatus is found throughout the world but is generally restricted to areas with domestic livestock. Solenopotes capillatus was reported by Kim to be the most frequent sucking louse encountered on Korea's livestock (as cited in Price and Graham 1997), and the louse was also identified in Europe and Australia in the early part of the 20th century (Matthysse 1946). Discovered in the United States in 1917, but not reported until 1921, the little blue cattle louse is the most abundant sucking cattle louse species in Wyoming and many areas of the east and southeast (Matthysse 1946, Price and Graham 1997).

\section{Description}

Eggs: The female louse lays one to two $0.7 \mathrm{~mm}$ eggs per day, each attached to a hair. Often the hair is bent, a feature not observed with other cattle lice.

1. This document is EENY-422, one of a series of Featured Creatures from the Entomology and Nematology Department, Florida Cooperative Extension Service, Institute of Food and Agricultural Sciences, University of Florida. Published: February 2009. This document is also available on Featured Creatures Website at http://creatures.ifas.ufl.edu. Please visit the EDIS Website at http://edis.ifas.ufl.edu. Additional information on these organisms, including many color photographs, is available at the Entomology and Nematology Department website at http://entnemdept.ifas.ufl.edu/.

2. Kevyn J. Juneau, graduate research assistant, and Phillip E. Kaufman, Entomology and Nematology Department, Cooperative Extension Service, Institute of Food and Agricultural Sciences, University of Florida, Gainesville, FL 32611.

The Institute of Food and Agricultural Sciences (IFAS) is an Equal Opportunity Institution authorized to provide research, educational information and other services only to individuals and institutions that function with non-discrimination with respect to race, creed, color, religion, age, disability, sex, sexual orientation, marital status, national origin, political opinions or affiliations. U.S. Department of Agriculture, Cooperative Extension Service, University of Florida, IFAS, Florida A. \& M. University Cooperative Extension Program, and Boards of County Commissioners Cooperating. Millie Ferrer, Interim Dean 


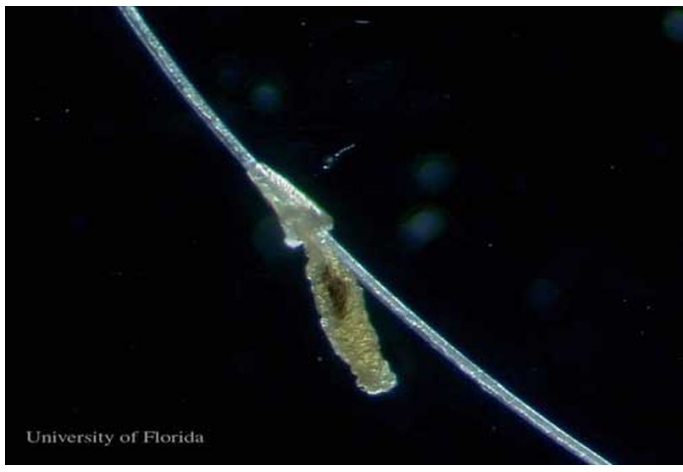

Figure 2. Egg of the little blue cattle louse, Solenopotes capillatus (Enderlein), cemented to a hair. Credits: Kevyn J. Juneau, University of Florida

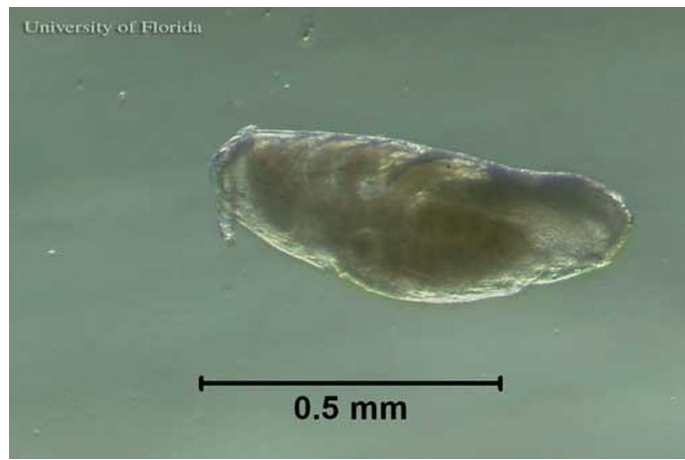

Figure 3. Ventral view of an adult little blue cattle louse, Solenopotes capillatus (Enderlein). Credits: Kevyn J. Juneau, University of Florida

Nymphs: First instars are smaller than the eggs at $0.69 \mathrm{~mm}$ and successively grow to $1.06 \mathrm{~mm}$ as a third instar.

Adults: Solenopotes capillatus has a short broad head, broad sensoria on segments four and five of the antennae, and it has a hexagonal shaped sternal plate on the thorax (Ignoffo 1959). The front tarsal claws are the smallest of the three pairs. The middle and hind tarsal claws are approximately the same size. Solenopotes capillatus has prominent abdominal tubercles that bear the spiracles. Adult males measure $1.08 \mathrm{~mm}$, similar to that of the third instars, while the adult females are $1.5 \mathrm{~mm}$ in length.

\section{Biology}

Solenopotes capillatus is a small louse, often confused with Linognathus vituli nymphs (Matthysse 1946), that feeds on the head, primarily the face and jaw regions, with sporadic occurrences on other body regions (Watson et al. 1997) of domestic livestock and captive ungulates. Once an individual establishes

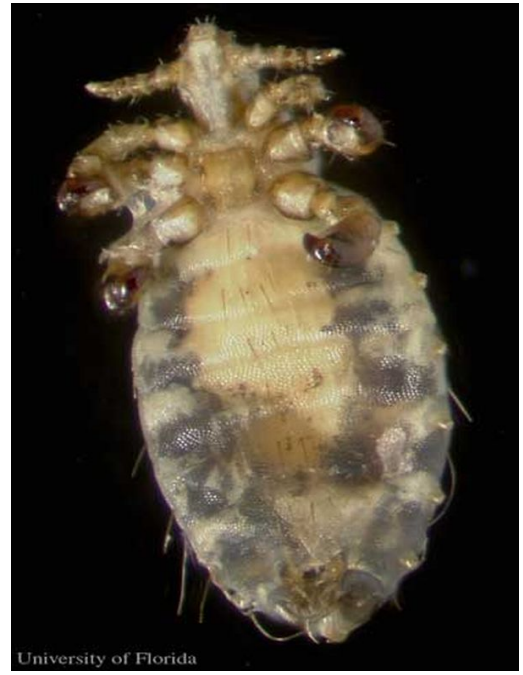

Figure 4. Ventral view of an adult little blue cattle louse, Solenopotes capillatus (Enderlein). Credits: Kevyn J. Juneau, University of Florida

itself on a host, it rarely relocates on the host's body (Skogerboe et al. 2000).

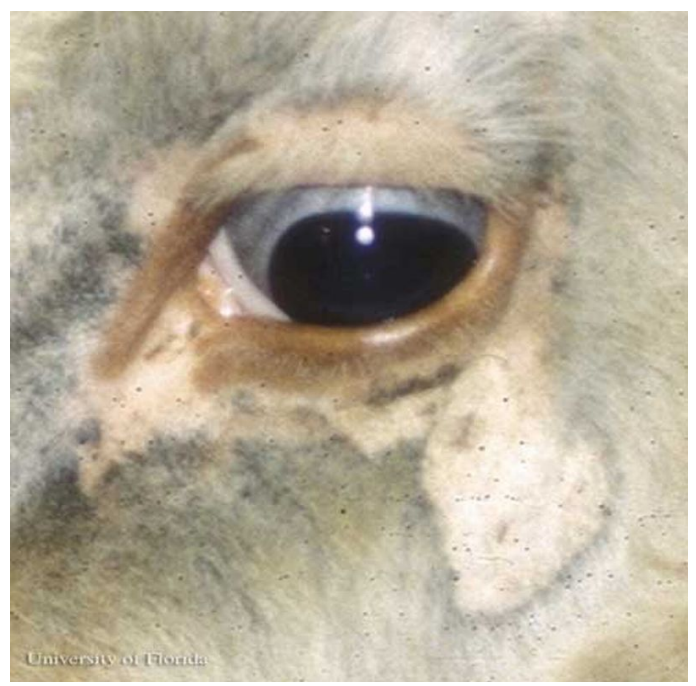

Figure 5. Infestation of the little blue cattle louse, Solenopotes capillatus (Enderlein), around the eye of a cow. Credits: Phillip Kaufman, University of Florida

The incubation period for the egg is about 12 days, and $S$. capillatus nymphs have three instars that each take approximately four to five days to develop. There is a preoviposition period of two days before the adult female begins to lay eggs. In total, it takes approximately 28 days to complete a life cycle from egg to oviposition. 


\section{Hosts}

Solenopotes capillatus feeds on a variety of ungulates but are most prolific on captive ungulates in zoos, such as gazelles (Yeruham et al. 1999), and those used for agriculture, specifically cattle.

Solenopotes capillatus congregate mostly on the face and may be so plentiful that the host appears to be wearing glasses (Townsend 2000). The lice are spread through direct contact between the cattle during mating, nursing, or other interactions such as herding. Older cows with longer hair and bulls that have large body mass are more prone to infestation because of the difficulty with self-grooming (Townsend 2000).

\section{Economic Importance}

Like most cattle lice, S. capillatus can cause irritation, restlessness, and some studies suggest lice may be linked to a decrease in milk production and poor quality hides for harvest (Nafstad and $\mathrm{Gr}^{-} \mathrm{nst}^{-1}$ 2001). Lice infestations cause the animal to scratch the areas infested, resulting in lesions or abrasions and areas of alopecia (hair loss) that can lead to bacterial or viral infections and insect infestations that cause the animal to become ill. A heavy load of lice may also cause the animal to become anemic (Holdsworth et al. 2006).

\section{Management}

Chemical control. Chemical treatments, including pour-on and dip insecticides, have historically been the primary method of louse control on cattle (Townsend 2000, Kaufman et al. 2001, White 2007). Recently, formulations administered subcutaneously have also been shown to be successful at treating lice (Cleale et al. 2004). Many new systemic insecticides require only one treatment for long-term louse control, but organophosphates and pyrethroids require two applications (Townsend 2000). Some formulations of pyrethroids and avermectin derivative-type treatments are the current recommendations for control of lice on lactating dairy cattle (Nafstad and Grnstl 2001). Dust bags placed in locations where the cattle are forced to use them provide easy application of insecticides (Kaufman et al. 2007).

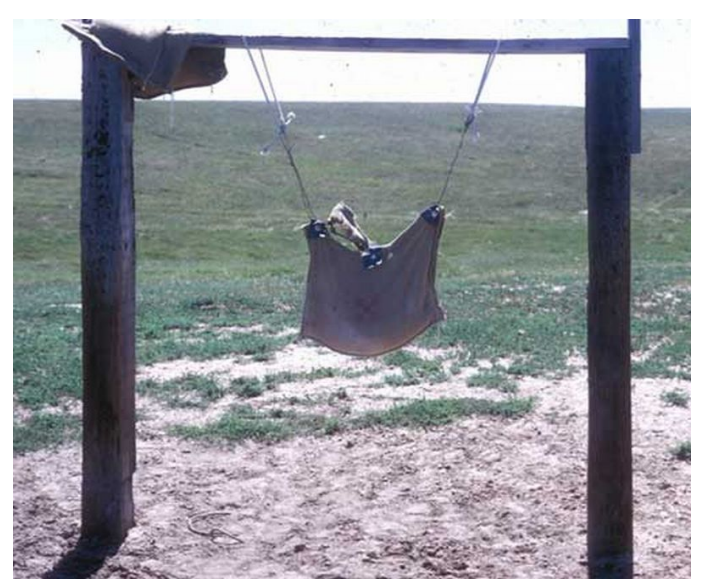

Figure 6. Dust bag used to apply insecticides to cows.

New cattle brought to a farm should be treated with an appropriate insecticide and kept separate from the herd until there is significant evidence that the animal is free of lice. This will eliminate the spread of lice between farms to reduce the chance of future infestations.

Non-chemical control. Clipping the animal's hair may help control the lice by rendering the microhabitat unsuitable (Allen and Dicke 1952). Providing special clothes and boots for visitors, especially veterinarians, may also reduce the chance of contaminating a louse-free farm (Nafstad and Gr'nst $^{-} 1$ 2001).

For additional information on cattle lice and their control, see the following UF/IFAS EDIS publications:

External Parasites of Dairy Cattle

http://edis.ifas.ufl.edu/IG050

External Parasites on Beef Cattle

http://edis.ifas.ufl.edu/IG130

Cattle Tail Lice

http://edis.ifas.ufl.edu/IG127

Management of External Parasites with Forced-Use Dust Bags

http://edis.ifas.ufl.edu/IG135

Management of External Parasites on Beef Cattle 
http://edis.ifas.ufl.edu/IG130

\section{Selected References}

Allen NN, Dicke RJ. 1952. Cattle lice control by clipping. Journal of Economic Entomology 45: 970-973.

Cleale RM, Lloyd JE, Smith LL, Grubbs MA, Grubbs ST, Kumar R, Amodie DM. 2004 Persistent activity of moxidectin long-acting injectable formulations against natural and experimentally enhanced populations of lice infesting cattle. Veterinary Parasitology 120: 215-227.

Durden LA, Musser GG. 1994. The sucking lice (Insecta: Anoplura) of the world: A taxonomic checklist with records of mammalian hosts and geographical distributions. Bulletin of the American Museum of Natural History No. 218, 90 p.

Ignoffo C. 1959. Key and notes to the Anoplura of Minnesota. American Midland Naturalist. 61: 470-479.

Grubbs MA, Lloyd JE, Kumar R. 2007. Life cycle details of Solenopotes capillatus (Anoplura: Linognathidae). Journal of Economic Entomology 100: 619-621.

Holdsworth PA, Vercruysse J, Rehbein S. Peter RJ, Letonja T, Green P. 2006. World Association for the Advancement of Veterinary Parasitology (W.A.A.V.P.) guidelines for evaluating the efficacy of ectoparasiticides against biting lice, sucking lice and sheep keds on ruminants. Veterinary Parasitology 136: 45-54.

Kaufman PE, Koehler PG, Butler JF. (2007). External parasites on beef cattle. EDIS. http://edis.ifas.ufl.edu/pdffiles/IG/IG13000.pdf (14 November 2007).

Kaufman PE, Rutz DA, Doscher ME, Albright R. 2001. Efficacy of chlorfenapyr (AC 303630) experimental pour-on and CyLence ${ }^{\circledR}$ formulations against naturally acquired louse infestations on cattle in New York. Veterinary Parasitology 97: 123-129.

Matthysse JG. 1946. Cattle lice: Their biology and control. Cornell University Agricultural Experiment Station Bulletin No. 832, 67 p.
Nafstad O, Gr-nst ${ }^{-1}$ H. 2001. Eradication of lice in cattle. Acta Veterinaria Scandinavica 42: 81-89.

Price MA, Graham OH. 1997. Chewing and sucking lice as parasites of mammals and birds. U.S. Department of Agriculture Technical Service Bulletin No. 1849, 309 p.

Skogerboe TL, Smith LL, Karle VK, Derozier CL. 2000. The persistent efficacy of doramectin pour-on against biting and sucking louse infestations of cattle. Veterinary Parasitology 87: 183-192.

Townsend L. (October 2000) Lice on beef and dairy cattle. University of Kentucky Cooperative Extension Service. http://www.ca.uky.edu/entomology/entfacts/ entfactpdf/ef512.pdf (14 November 2007).

Watson DW, Lloyd JE, Kumar R. 1997. Density and distribution of cattle lice (Phthiraptera: Haematopinidae, Linognathidae, Trichodectidae) on six steers. Veterinary Parasitology 69: 283-296.

White WH, Hutchens DE, Jones C, Larry D, Firkins LD, Paul AJ, Smith LL, Snyder DE. 2007. Therapeutic and persistent efficacy of spinosad applied as a pour-on or a topical spray against natural infestations of chewing and sucking lice on cattle. Veterinary Parasitology 143: 329-336.

Yeruham I, Rosen S, Hadani A. Braverman Y. 1999. Arthropod parasites of nubian ibexes (Capra ibex nubiana) and gazelles (Gazella gazella) in Israel. Veterinary Parasitology 83: 167-173. 